\title{
Doctorate education and producing knowledge in nursing
}

\author{
Maria Helena Palucci Marziale \\ Regina Aparecida Garcia de Lima
}

Nowadays, knowledge and innovation are viewed as central factors to sustainable economic growth and development. Close cooperation between university, society and the system of production is therefore indispensable. Scientific and technological advances and innovation depend on policies and strategies that involve the academic community, scientific societies, professionals and social actors. In this process, strictu sense postgraduate courses, especially doctorates, have contributed to developments in science and technology and innovations, deemed to be the motors of social and economic change.

As with other areas of knowledge, doctorate programs in Nursing have contributed significantly to advances in the sciences. In nursing, studies resulting from doctoral theses have ensures leadership and quality in providing health care services. Over the history of doctorate education in Nursing, which began in the 1930s, socio-political and economic changes have taken place that impacted directly on the quality and quantity of scientific output in the area, on consolidating the knowledge produced and on nursing practice. Currently, there are new demands, especially national and international mobilization of the area to deal with the challenges faced in the period of doctorate education, market demands regarding work and the quality of doctoral theses, regarding applying knowledge produced to practice.

Thus, with the aim of supporting reflection and disseminating information on current demand, this edition of the Revista Latino-Americana de Enfermagem has been specially designed. It is a dossier of five articles by researchers who have been invited to analyze doctorate education in Nursing and the production of knowledge stemming from doctoral theses, together with a further 10 articles, the results of theses, revealing the quality of scientific output.

Shaké Ketefian and Richard Redman present a critical analysis of doctorate education in the United States, based on educational and social trends and changes takin place in Nursing postgraduate courses in that country, especially concerning the length of time taken to achieve the qualification and the need to increase the number of scientists in nursing and nurses with clinical experience to operate using advanced practices, resolving the main health problems present in society. The article contains many recommendations that will certainly have implications for international nursing, given the historical influence of American nursing.

Maria José López-Montesinos et al analyze the structural change undergone in education for European nurses and access to Nursing doctorate programs in Spain, contextualizing the challenges faced in the initial stages of implanting lines of research appropriate to the area and the achievements of the movement led by Nursing doctorates there.

Sandra Valenzuela-Suazo et al analyze doctorate education in Nursing in Chile, since postgraduate courses began there. They describe the aspects that made it difficult to develop these courses and highlight the limited appreciation of Nursing as an area of knowledge, the lack of institutional policies aimed at doctorate education in Nursing, postgraduate students' places in the academic and care areas and the limited number of grants available. The authors believe that establishing conventions with national and international institutions to develop partnerships and research together may help to consolidate doctoral education in Nursing in Chile.

Carmem Gracinda Silvan Scochi, representative of the Nursing area in the Coordination of Higher Education Personnel Improvement (Coordenação de Aperfeiçoamento de Pessoal de Nível Superior - CAPES), et al discuss the historical aspects of doctorate education in nursing worldwide and in Brazil and analyze education and scientific output using the different disciplines delivered, internationalization strategies and doctorate theses defended in Brazilian postgraduate programs. The results of the study reveal advances in the number of disciplines offered over the threeyear-period analyzed and in the internationalization initiatives adopted by the programs. As for production of knowledge, 
the authors identified that the doctorates' focus is centered on conducting descriptive studies of the health care and nursing process. The authors show the need to propose more robust research projects with greater potential to produce hard scientific evidence, in order to be applied to professional practice, and warn about the need to broaden internationalization strategies in postgraduate programs.

Rosalina Partezani Rodrigues et al analyze Nursing doctorate theses focusing on achievement of millennium goals, aimed at combatting poverty and other social evils. The study identified that Brazilian doctorate theses in Nursing, defended during the three-year-period analyzed, have little relationship to the achievement of the millennium goals, although they cover economic development and health conditions and quality of life in the population. The authors recommend that studies conducted during doctorate education in Nursing are aimed at increasing knowledge and focus on concrete problems and needs of society.

The other articles that make up this dossier are the result of doctorate theses in Nursing, a selected sample of scientific output that shows the different facets and approaches of advanced practice in nursing.

We hope you enjoy reading them.

Maria Helena Palucci Marziale is Chief Scientific Editor of the Revista Latino-Americana de Enfermagem and Full Professor of the Escola de Enfermagem de Ribeirão Preto, Universidade de São Paulo, PAHO/WHO Collaborating Centre for Nursing Research Development, Ribeirão Preto, SP, Brazil. E-mail: marziale@eerp.usp.br.

Regina Aparecida Garcia de Lima is Scientific Editor of the Revista Latino-Americana de Enfermagem and Full Professor of the Escola de Enfermagem de Ribeirão Preto, Universidade de São Paulo, PAHO/WHO Collaborating Centre for Nursing Research Development, Ribeirão Preto, SP, Brazil. E-mail: limare@eerp.usp.br. 